UDC 613,$1 ; 614,7$

DOI: 10.21668/health.risk/2018.3.06.eng

Read

\title{
FACTORS AND POPULATION HEALTH RISKS UNDER EXPOSURE TO COMPONENTS DETECTED IN DRINKING WATER WITHIN NATURAL HYDROGEOCHEMICAL PROVINCES IN PERM REGION
}

\author{
A.N. Fomenko ${ }^{1}$, V.A. Aristov², O.A. Maklakova ${ }^{2}$, V.A. Khoroshavin ${ }^{3}$ \\ ${ }^{1}$ Federal Service for Surveillance over Consumer Rights Protection and Human Well-being, Perm Regional Office, \\ 50 Kuybyisheva Str., Perm, 614016, Russian Federation \\ ${ }^{2}$ Perm State University, 15 Bukireva Str., Perm, 614990, Russian Federation \\ ${ }^{3}$ Center for Hygiene and Epidemiology in Perm region, 50A Kuybyisheva Str., Perm, 614016, Russian Federation
}

Our research goal was to assess health risks for population who consumed drinking water with specific chemical structure systematically and for a long time. Drinking water quality is determined by conditions existing in hydrogeochemical provinces where rocks and soils contain increased concentrations of such hazardous metals as chromium, nickel, lead, manganese, and iron. We showed that low frequency or even absence of nonconformity to hygienic standards for admixtures in drinking water doesn't fully guarantee its safety in complicated hydrogeochemical conditions.

When certain carcinogenic admixtures (cadmium, chromium, nickel, arsenic, and lead) occur together in drinking water even in low concentrations, it can cause unacceptable population health risks. Drinking water taken in examined geochemical provinces in Perm region causes individual lifelong carcinogenic risk which is (under the worst exposure scenarios) equal to $4 \cdot 10^{-3}$. It can be ranked as De manifestis Risk and requires immediate measures to be taken by those responsible to reduce it. Unacceptable non-carcinogenic risks are caused by joint concentrations of arsenic, strontium, and some other compounds in drinking water. The highest risks existing on the examined territories were detected in relation to gastrointestinal tract diseases (HI up to 10.9, basic risk factor is chromium and its compounds), musculoskeletal system diseases (HI up to 11.8, strontium as a basic factor), and central nervous system diseases (HI up to 11.8, basic factors are arsenic, manganese, and lead). Contributions made by various elements into overall risks were different in different provinces.

In some cases, when a certain element occurs in the crust in hazardous concentrations, its contents in drinking water are not observed. We recommend organizations that deal with water supply and sanitary surveillance bodies to take into account peculiarities of a geochemical province and to include admixtures that are contained in the environment in high quantities into monitoring programs and laboratory research.

Key words: geochemical province, drinking water, chemical structure, safety, health risk.

The supreme governmental bodies in our country rank provision of population with qualitative and, consequently, safe drinking water among top priorities of the state ${ }^{1}$. The task is not simple as quality of water which is supplied to consumers depends on multiple factors, such as natural composure of water taken from this or that water source, anthropogenic influence (primarily, vol-

(c) Fomenko A.N., Aristov V.A., Maklakova O.A., Khoroshavin V.A., 2018

Aleksandr N. Fomenko - Chief expert of Department for surveillance over communal hygiene (e-mail: fomienko_87@mail.ru; tel.: +7 (342) 239-34-80).

Vladislav A. Aristov - bachelor at Department for Human Ecology and Life Safety (e-mail: root@ fcrisk.ru; tel.: +7 (342) 237-18-04).

Ol'ga A. Maklakova - Associate Professor at Department for Human Ecology and Life Safety (e-mail: olga mcl@ fcrisk.ru; tel.: +7 (342) 237-27-92).

Viktor A. Khoroshavin - Doctor of Medical Sciences, Chief Physician (e-mail: cgepo@ mail.ru; tel.: +7 (342) 239-34-09).

${ }^{1}$ On national goals and strategic tasks in the development of the Russian Federation up to 2024: The RF President Order. President of Russia: official web-site. Available at: http://www.kremlin.ru/events/president/news/574 25 (access date 20.06.2018). 
umes and composure of sewage water discharged into surface water sources or pumped into underground water horizons), water treatment technologies and reactants applied in the process, state of infrastructure etc. [1-3]. Anthropogenic pollution, technical and technological equipment of water treatment systems are manageable factors, while it is practically impossible to change natural chemical structure of a water objects by means that are contemporarily available to us. The situation becomes even more complicated in such cases when a water source that doesn't fully correspond to hygienic requirements has no alternatives or all the water objects located on a specific territory are very similar in their chemical structure due to its natural geochemical peculiarities. The latter is quite typical of hydrogeochemical provinces and it is quite often a very complicated task to supply qualitative and safe drinking water to people who live there. For example, experts detected natural arsenous anomalies in such countries as Argentina, Nepal, Cambodia, Ghana, China, Bangladesh, and Iran; these anomalies exerted substantial impacts on quality of natural and drinking water $[4,5]$. One-shot examinations allowed to obtain data on As concentrations in water reaching $2,500 \mathrm{mg} / \mathrm{l}$ and it means such water was unsafe for people's health [6].

Experts from Turkey mention problems related to natural increased concentrations of $\mathrm{Pb}$ in drinking water sources [7]. Hazardous concentrations of $\mathrm{U}, \mathrm{As}$, and Se in underground waters consumed by population were described in works by Mongolian experts [8]. High concentrations of fluorides cause unacceptable health risks for people living in Mastung, Mangochar, and Pringabad regions of Baluchistan province in Pakistan $[9,10]$ etc.

As per data provided by some experts, there are large regions in Russia where underground drinking water contains increased concentrations of toxic elements and causes health disorders among population [11]. Thus, quality of underground water in the Republic of Dagestan was studied, and, given the basic geochemical preconditions, it allowed to reveal that natural processes that occurred in the north part of the Republic caused formation of a regional hydrogeochemical province where underground water contained increased As concentration, up to 20 MPC [12]. Voteiko highlights functional disorders in the kidneys that occur in Zabaikalsaya biogeochemical province with increased Se concentrations [13]. As per data by A.V. Abramkin, a hyper-fluoric biogeochemical province that formed in the Republic of Mordovia causes endemic fluorosis in people who live there [14]. There are territories with increased natural $\mathrm{Rn}$ concentrations that cause risks of radiation exposure for population [15].

Overall, there are several basic factors that determine a possibility of high toxic elements concentration in surface and underground water taken from drinking water supply sources within boundaries of specific hydrogeochemical provinces. They are:

- rocks with relatively high concentrations of such substances; rocks;

- high leaching capability of water-containing

- variability of states in which elements occur in rocks, including easily soluble compounds;

- favorable hydrogeological and hydrochemical conditions determined by high speed of water exchange and chemical types of water;

- intense exploitation of underground water which is used for communal and household water supply; it makes for active interaction between different water-bearing horizons, makes water exchange faster, and enhances intensity of physical and chemical interactions within "water-rock" systems.

Perm region is a territory with a complicated geological structure and diverse chemical composure of its soil and subsoil. There are 14 geochemical provinces in the region and each of them has increased concentrations of specific non-organic compounds (Figure). Accordingly, peculiarities of underlying rocks and soils within these provinces exert their influence on chemical composure of water sources which are used to supply drinking water to population [16, 17]. And there are elements and compounds registered in the provinces and specific for this or that one with proven negative influence on population health even in insignificant concentrations. These elements and compounds are $\mathrm{Pb}, \mathrm{Cd}, \mathrm{Ni}$, $\mathrm{Cr}, \mathrm{Mn}, \mathrm{V}$ and others (Table 1).

Our research goal was to assess risks of health disorders occurrence among people who permanently and for a long time consumed drinking water with chemical structure characteristic for some geochemical provinces in Perm region.

Data and methods. Boundaries of geochemical provinces were fixed as per data taken from the atlas drawn up by Geokarta-Perm Geological Party as vector layers of GIS ArcView format and scaled 1:1000000. Places were water intake points were located were determined as per data provided by the Perm Regional Office of the Federal Service for Surveillance over Consumer Rights Protection and $\mathrm{Hu}-$ man Well-being. We connected water sources and spatial intersection of water intake points and geochemical provinces in GIS ArcView 3.2 (ESRI, the USA). 


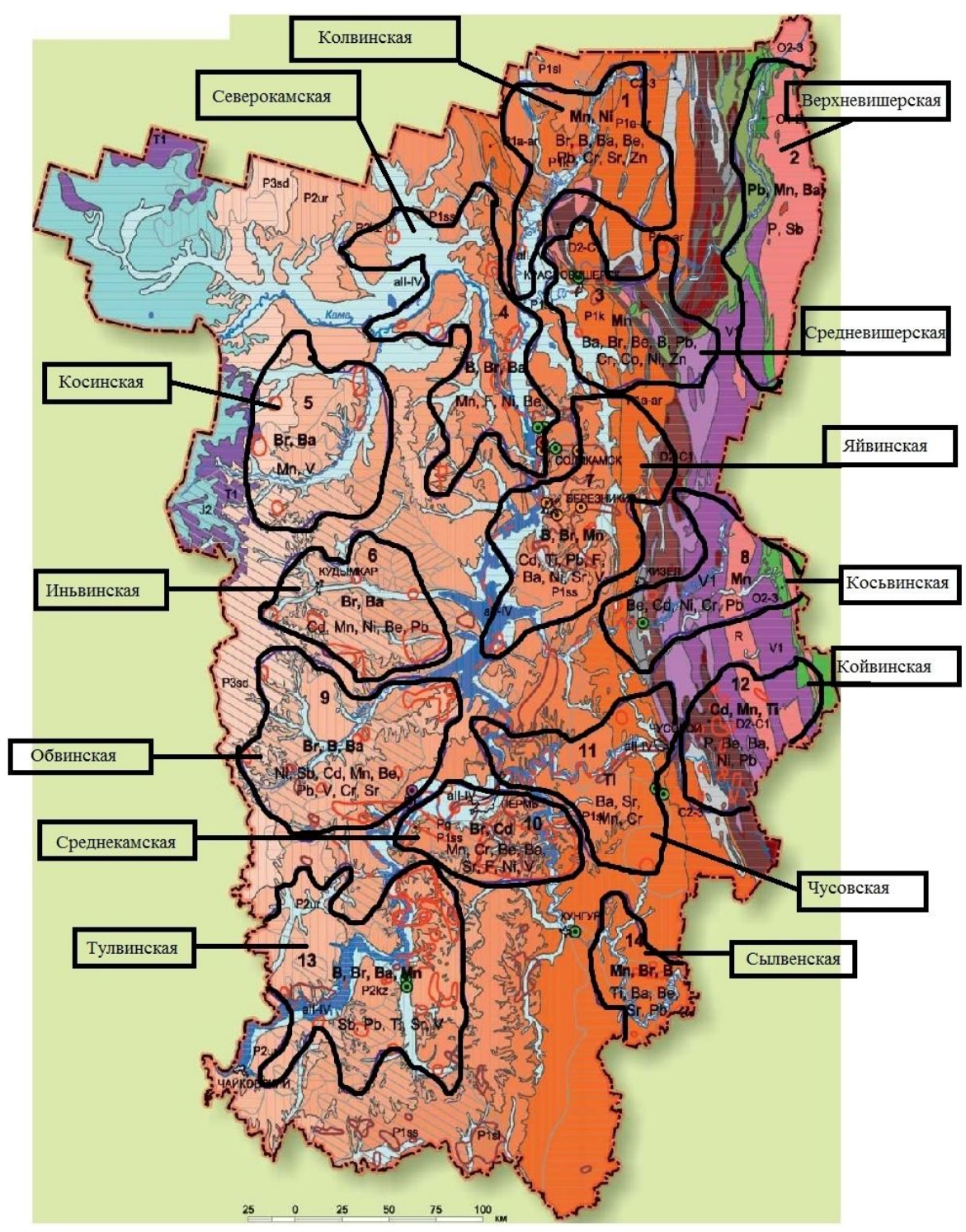

Figure. Geochemical provinces in Perm region [2]

Table 1

Environmental components in geochemical provinces located in Perm region:

peculiarities of chemical structure

\begin{tabular}{|l|l|l|}
\hline \multirow{2}{*}{\multicolumn{2}{|c|}{ Geochemical province }} & \multicolumn{2}{c|}{ Chemical structure and its peculiarities } \\
\cline { 2 - 3 } & \multicolumn{1}{|c|}{ Areal prevalence } & \multicolumn{1}{c|}{ Spotted prevalence } \\
\hline Kolvinskaya & $\mathrm{Mn}, \mathrm{Ni}$ & $\mathrm{B}, \mathrm{Br}, \mathrm{Ba}, \mathrm{Be}, \mathrm{Pb}, \mathrm{Cr}, \mathrm{Sr}, \mathrm{Zn}$ \\
\hline Verkhnevisherskaya & $\mathrm{Pb}, \mathrm{Mn}, \mathrm{Ba}$ & $\mathrm{P}, \mathrm{Sb}$ \\
\hline Srednevisherskaya & $\mathrm{Mn}$ & $\mathrm{Ba} \mathrm{Br}, \mathrm{Be} \mathrm{B}, \mathrm{Pb}, \mathrm{Cr}, \mathrm{Co}, \mathrm{Ni}, \mathrm{Zn}$ \\
\hline Yay'vinskaya & $\mathrm{B}, \mathrm{Br}, \mathrm{Mn}$ & $\mathrm{Cd}, \mathrm{Ti}, \mathrm{Pb}, \mathrm{F}, \mathrm{Ba}, \mathrm{Ni}, \mathrm{Sr}, \mathrm{V}$ \\
\hline Kosinskaya & $\mathrm{Br}, \mathrm{Ba}$ & $\mathrm{Mn}, \mathrm{V}$ \\
\hline Koyvinskaya & $\mathrm{Cd}, \mathrm{Mn}, \mathrm{Ti}$ & $\mathrm{P}, \mathrm{Be}, \mathrm{Ba}, \mathrm{Ni}, \mathrm{Pb}, \mathrm{B}, \mathrm{Br}$ \\
\hline Chusovskaya & $\mathrm{Ti}$ & $\mathrm{Ba}, \mathrm{Sr}, \mathrm{Mn}, \mathrm{Cr}$ \\
\hline Sylvenskaya & $\mathrm{Mn}, \mathrm{B}, \mathrm{Br}$ & $\mathrm{Ti}, \mathrm{Ba}, \mathrm{Be}, \mathrm{Sr}, \mathrm{Pb}$ \\
\hline Tulvinskaya & $\mathrm{B}, \mathrm{Br}, \mathrm{Ba}, \mathrm{Mn}$ & $\mathrm{Sb}, \mathrm{Pb}, \mathrm{Ti}, \mathrm{Sr}, \mathrm{V}$ \\
\hline Srednekamskaya & $\mathrm{Br}, \mathrm{Cd}$. & $\mathrm{Mn}, \mathrm{Cr}, \mathrm{Be}, \mathrm{Ba}, \mathrm{Sr}, \mathrm{F}, \mathrm{Ni}, \mathrm{V}$ \\
\hline Obvinskaya & $\mathrm{Br}, \mathrm{B}, \mathrm{Ba}$ & $\mathrm{Sb}, \mathrm{Cd}, \mathrm{Mn}, \mathrm{Be}, \mathrm{Pb}, \mathrm{V}, \mathrm{Cr}, \mathrm{Sr}$ \\
\hline In'vinskaya & $\mathrm{Br}, \mathrm{Ba}$ & $\mathrm{Cd}, \mathrm{Mn}, \mathrm{Ni}, \mathrm{Be}, \mathrm{Pb}$ \\
\hline Kos'vinskaya & $\mathrm{Mn}$ & $\mathrm{Be}, \mathrm{Cd}, \mathrm{Ni}, \mathrm{Cr}, \mathrm{Pb}$ \\
\hline Severokamskaya & $\mathrm{Br}, \mathrm{B}, \mathrm{Ba}$ & $\mathrm{Mn}, \mathrm{F}, \mathrm{Ni}, \mathrm{Be}$ \\
\hline
\end{tabular}


To assess risks, we chose 3 geochemical provinces where large water intakes were located; they were used to supply water into centralized drinking water supply systems.

Sylvenskaya geochemical province. It is located on the south-east of Perm region and includes central and southern parts of Suksunskiy district and the north of Kishertskiy region. This province is characterized with increased concentrations of $\mathrm{B}, \mathrm{Ba}, \mathrm{Sr}$ (clarke ${ }^{2}$ is about 3.1), $\mathrm{Pb}$ (clarke is 1.3), Mn (clarke is 15.5). There are water intakes located in the province on Sylva river near Suksun settlement; they supply water to more than 8.3 thousand people.

Koyvinskaya geochemical province. It is located in the east of the region and includes the central part of Gornozavodskiy district, the east of Chusovskoy district and the north of Lys'venskiy district. This province is characterized with increased concentrations of $\mathrm{Cd}, \mathrm{Mn}, \mathrm{Pb}$, and $\mathrm{Ni}$, $\mathrm{Cd}$ clarke reaches 25 and $\mathrm{Mn}, 15.4$, and it is substantially higher than in other parts of the region. There are large water intake in the province located on Pashiyka river (Pashya settlement, 4.1 thousand people) in the central part of Gornozavodskiy district, and on Chusovaya river near Voronovka settlement (about 2.000 people) in the south of Gornozavodskiy district.

Chusovskaya geochemical province. It is located in the central part of Perm region and includes the central part of Chusovskoy district, a small part of Dobryanskiy district in the east, Gremyachnskiy district in the south, and Lys'venskiy district in the north-west. It has the most variable chemical structure as per various metals that can be found there; there are increased concentrations of $\mathrm{Mn}$ (clarke is 23.0), $\mathrm{Cu}$ (clarke is 3.0), $\mathrm{Fe}$ (clarke is 10.0), and Mo (clarke is 11.0). There are some large water intakes located in this province, including those on Chusovaya river in Chusovoy town $(48,521$ people), on Lys'va river in Kalino settlement (2,425 people), Komarikhinskiy settlement, and some others. The province is characterized with increased concentrations of $\mathrm{Mn}, \mathrm{Cr}$. $\mathrm{Fe}$, and Ni.
We assessed quality of drinking water taken from centralized drinking water supply systems as per data provided by the Center for Hygiene and Epidemiology in Perm region; the data were obtained during control and surveillance activities and social and hygienic monitoring; some data were submitted by laboratories of water supplying organizations (results of industrial control performed with conventional techniques). When analyzing quality of drinking and natural water, we examined results of profound chemical and sanitary analysis obtained for an observation period from 2011 to 2016. Heavy metals were examined with atomic absorption analysis that allowed to indentify smallest concentrations, up to 0.0001 $\mathrm{mg} / \mathrm{sample}$. We analyzed more than 12,000 results of tests performed on water intakes in Gornozavodskiy district (Pahiyka river, Chusovaya river), Chusovskoy district (Chusovaya river, Lys'va river), Kungurskiy district (Kama river, Yug river), and Suksunskiy district (Sylva river) and others.

Risk assessment methodology was chosen as an efficient instrument for preliminary analysis of the situation; this analysis didn't require substantial financial and organizational costs and simultaneously allowed us to obtain information for further managerial actions [18]. We assessed risks in conformity with the "Guidelines on assessment of population health risks..." ${ }^{3}$, and considered adverse effects on health described in the document (Table 2). Lifelong carcinogenic risk equal to $1 * 10-4$ was considered to be acceptable. Hazard index value equal to 1.0 was considered to be acceptable non-carcinogenic risk.

We preset the following exposure scenario: daily water consumption for 350 days per year, with water quality being the same as it was determined at the moment of the research; the period for calculation of carcinogenic risks was equal to 30 years, and non-carcinogenic risks, 70 years. Bearing the precautionary principle in mind, we examined concentrations of admixtures in drinking water at $95 \%$ percentile level over the whole observation period.

We took standard parameters of drinking

\footnotetext{
${ }^{2}$ Clarke value (or clarkes of elements, more often, just clarke) are values that describe average concentration of chemical elements in earth crust, hydrosphere, the Earth, cosmic bodies, geochemical or cosmochemical systems etc., against the overall mass of this system. they are usually given in $\%$ or $\mathrm{g} / \mathrm{kg}$.

${ }^{3} \mathrm{P} 2.1 .10 .1920-04$. Guidelines on assessment of population health risks under exposure to chemicals that pollute environment. Moscow, Federal Center for state sanitary and epidemiologic surveillance of the RF Public Healthcare Ministry, 2004, 143 p.
} 
Table 2

Parameters applied in assessing health risks under exposure to chemical admixtures consumed with drinking water

\begin{tabular}{|l|c|l|c|}
\hline Element & $R f D, \mathrm{mg} / \mathrm{kg}$-day & \multicolumn{1}{|c|}{ Critical organs and systems } & $S F^{*}$ \\
\hline $\mathrm{Ba}$ & 0,07 & Kidneys, cardiovascular system & - \\
\hline $\mathrm{B}$ & 0,2 & Reproductive system, gastrointestinal tract & - \\
\hline $\mathrm{Fe}$ & 0,30 & Mucous tunics, skin, blood, immune system & - \\
\hline $\mathrm{Cd}$ & 0,0005 & Kidneys, endocrine system & - \\
\hline $\mathrm{Mn}$ & 0,14 & Central nervous system, blood & - \\
\hline $\mathrm{Cu}$ & 0,019 & Gastrointestinal tract & - \\
\hline $\mathrm{Mo}$ & 0,005 & Kidneys & 1,5 \\
\hline $\mathrm{As}$ & 0,0003 & $\begin{array}{l}\text { Skin, central nervous system, cardiovascular immune, and endocrine } \\
\text { systems, gastrointestinal tract }\end{array}$ & 1,7 \\
\hline $\mathrm{Ni}$ & 0,02 & Liver, cardiovascular system, gastrointestinal tract, blood, body weight & 1,7 \\
\hline $\mathrm{Pb}$ & 0,0035 & $\begin{array}{l}\text { Central nervous system, peripheral nervous system, blood, development, } \\
\text { reproductive system, endocrine system }\end{array}$ & 0,047 \\
\hline $\mathrm{Sr}$ & 0,6 & Kidneys, cardiovascular system & - \\
\hline $\mathrm{Ti}$ & 4,00 & Reproductive system, gastrointestinal tract & - \\
\hline $\mathrm{Cr}$ & 0,005 & Mucous tunics, skin, blood, immune system & 0,42 \\
\hline
\end{tabular}

Note: *-Carcinogenic potential factor for carcinogens

water consumption and body weight to calculate daily doses [2].

Basic results. Results collected over a long period of time, including those obtained via comprehensive sanitary analysis of examined drinking water, revealed that research structure was similar for different water supply sources. Control programs (both industrial and state one) pay little attention to hydrogeochemical peculiarities of territories. $\mathrm{B}$ and $\mathrm{Br}$ are admixtures that are characteristic for some geochemical provinces and it is well proven that they produce adverse effects under oral exposure. However, these admixtures are not controlled either by water supplying organizations or sanitary surveillance bodies. Sanitary analysis of drinking water from water intakes located in Chusovskaya province didn't include $\mathrm{Sr}$ concentrations although the element is specific for geological rocks that form natural waters there.

Metals, including heavy and amphoteric ones, cause the most serious population health risks as a results of long-term consumption of drinking water in the examined geochemical provinces. Such metals were registered in water practically everywhere (Table 3 ).

Average long-term daily concentrations of priority chemical admixtures in drinking water supplied to population, $\mathrm{M} \pm \mathrm{m}, \mathrm{mg} / \mathrm{dm}^{3}$

\begin{tabular}{|l|c|c|c|}
\hline \multirow{2}{*}{ Chemical element } & \multicolumn{3}{|c|}{ Geochemical province } \\
\cline { 2 - 4 } & Sylvenskaya & Koyvinskaya & Chusovskaya \\
\hline $\mathrm{Mn}$ & $0,005 \pm 0,0008$ & $0,05 \pm 0,0075$ & $0,01 \pm 0,0015$ \\
\hline $\mathrm{Cd}$ & $0,0002 \pm 0,0001$ & $0,0002 \pm 0,0001$ & Not measured \\
\hline $\mathrm{Fe}$ & $0,0500 \pm 0,0075$ & $0,31 \pm 0,05$ & $1,1 \pm 0,13$ \\
\hline $\mathrm{Pb}$ & $0,0012 \pm 0,0003$ & $0,0001 \pm 0,0001$ & Not measured \\
\hline $\mathrm{Ni}$ & $0,0065 \pm 0,0012$ & $0,0071 \pm 0,015$ & $0,0075 \pm 0,015$ \\
\hline $\mathrm{Cr}$ & $0,010 \pm 0,006$ & $0,012 \pm 0,007$ & $0,018 \pm 0,003$ \\
\hline $\mathrm{Mo}$ & Not measured & $0,003 \pm 0,0004$ & $0,003 \pm 0,0001$ \\
\hline $\mathrm{Cu}$ & $0,005 \pm 0,001$ & $0,004 \pm 0,001$ & $0,02 \pm 0,003$ \\
\hline $\mathrm{Ba}$ & Ltd1* & Ltdl & Not measured \\
\hline $\mathrm{As}$ & $0,0025 \pm 0,0005$ & $0,001 \pm 0,0003$ & $0,0005 \pm 0,0001$ \\
\hline $\mathrm{Sr}$ & $7,30 \pm 1,22$ & Not measured & Not measured \\
\hline
\end{tabular}

Note: *-means lower than detection limit 
Hygienic standards for specific admixtures contents were violated extremely rarely (less than $1 \%$ of the overall number of examined samples). Assessment of lifelong carcinogenic risk revealed that the overall situation with drinking water safety was rather alarming. Levels of lifelong carcinogenic risk calculated as per maximum contamination varied from $2.99 * 10-4$ to $4.01 * 10^{-3}$ and were considered unacceptable (Table 4).

Recalculation of carcinogenic risk per average lifelong value allowed to assess risks as substantially less significant however they still were above the upper permissible limit of acceptable risk (1.9*10-4 in Sylvenskaya province; $2.3 * 10^{-4}$ in Koyvinskaya province, and $2.99 * 10^{-4}$ in
Chusovskaya province). Basic contribution into carcinogenic health risks for population was made by $\mathrm{Ni}$ in all three provinces. Concentration of this component in natural water sources is to be analyzed more profoundly. It is necessary to estimate a determination procedure in terms of validity and precision of its results. It also seems vital to examine seasonal fluctuations in admixtures contained in drinking water and to detect primary sources of $\mathrm{Ni}$ introduction into it.

Unacceptable non-carcinogenic health risks for population who permanently consume drinking water with quality outlined above occur as regards a number of organs and systems (Table 5).

Table 4

Average long-term concentration of certain chemical elements in drinking water from water intakes located within geochemical provinces

\begin{tabular}{|c|c|c|c|c|}
\hline Element & $\begin{array}{c}\text { Average long-term concentration, } \\
95 \% \text { percentile, } \\
\mathrm{mg} / \mathrm{dm} 3\end{array}$ & Dose, $\mathrm{mg} / \mathrm{kg}$-day & Carcinogenic risk & $\begin{array}{c}\text { Factor } \\
\text { contribution into } \\
\text { risk, } \%\end{array}$ \\
\hline \multicolumn{5}{|c|}{ Sylvvenskaya province } \\
\hline $\mathrm{Cd}$ & 0,00025 & $6,85 \mathrm{E}-06$ & $2,60 \mathrm{E}-06$ & 0,5 \\
\hline $\mathrm{Pb}$ & 0,0015 & $4,11 \mathrm{E}-05$ & $1,93 \mathrm{E}-06$ & 0,4 \\
\hline $\mathrm{Ni}$ & 0,0075 & $2,05 \mathrm{E}-04$ & $3,49 \mathrm{E}-04$ & 71,7 \\
\hline $\mathrm{Cr}$ & 0,0180 & $2,44 \mathrm{E}-05$ & $8.89 \mathrm{E}-05$ & 18,3 \\
\hline As & 0,0030 & $2.94 \mathrm{E}-05$ & $4,40 \mathrm{E}-05$ & 9,0 \\
\hline \multicolumn{3}{|c|}{ Overall carcinogenic risk } & 3,98E-04 (unacceptable) & \\
\hline \multicolumn{4}{|c|}{ Koyvinskaya province } & \\
\hline $\mathrm{Cd}$ & 0,00057 & $2,00 \mathrm{E}-05$ & $5,93 \mathrm{E}-06$ & 0,10 \\
\hline $\mathrm{Pb}$ & 0,0001 & $1,00 \mathrm{E}-06$ & $1,29 \mathrm{E}-07$ & 0,0 \\
\hline $\mathrm{Ni}$ & 0,0080 & $2,19 \mathrm{E}-03$ & 3,73E-03 & 93,1 \\
\hline $\mathrm{Cr}$ & 0,0200 & $5,50 \mathrm{E}-04$ & $2,30 \mathrm{E}-04$ & 5,75 \\
\hline As & 0,0010 & $3,00 \mathrm{E}-05$ & $4,11 \mathrm{E}-05$ & 1,03 \\
\hline \multicolumn{3}{|c|}{ Overall carcinogenic risk } & 4,01E-03 (unacceptable) & \\
\hline \multicolumn{4}{|c|}{ Chusovskaya province } & \\
\hline $\mathrm{Ni}$ & 0,0082 & $9,63 \mathrm{E}-05$ & $1,64 \mathrm{E}-04$ & 54,7 \\
\hline $\mathrm{Cr}$ & 0,0250 & $2,94 \mathrm{E}-04$ & 1,23E-04 & 41,2 \\
\hline As & 0,0007 & $8,22 \mathrm{E}-06$ & $1,25 \mathrm{E}-05$ & 4,12 \\
\hline \multicolumn{3}{|c|}{ Overall carcinogenic risk } & 2,99-04 (unacceptable) & \\
\hline
\end{tabular}

Admixtures with carcinogenic effects - $\mathrm{Cd}, \mathrm{Pb}$, and $\mathrm{Ni}$ compounds

\begin{tabular}{|l|c|l|c|l|l|l|}
\hline \multirow{2}{*}{ Target organs (systems) } & $H I$ & Priority risk factors & $H I$ & \multicolumn{1}{|c|}{ Priority risk factors } & $H I$ & $\begin{array}{c}\text { Priority risk } \\
\text { factors }\end{array}$ \\
\cline { 2 - 8 } & \multicolumn{2}{|c|}{ Sylvenskaya province } & \multicolumn{3}{|c|}{ Koyvinskaya province } & Chusovskaya province \\
\hline Kidneys & 1,4 & $\mathrm{Cr}$ & 3,4 & $\mathrm{Cr}, \mathrm{Mo}$ & 4,2 & $\mathrm{Cr}$ \\
\hline Gastrointestinal tract & 10,9 & $\mathrm{Cr}, \mathrm{As}$ & 6,3 & $\mathrm{Cr}, \mathrm{As}$ & 6,7 & $\mathrm{Cr}, \mathrm{As}, \mathrm{Cu}$ \\
\hline Central nervous system & 11,8 & $\mathrm{As}, \mathrm{Pb}$ & 3,7 & $\mathrm{As}, \mathrm{Mn}$ & 1,7 & $\mathrm{As}$ \\
\hline Cardiovascular system & 8,7 & $\mathrm{As}$ & 3,7 & $\mathrm{As}$ & 2,0 & $\mathrm{As}$ \\
\hline Blood & 4,0 & $\mathrm{~Pb}$ & 1,8 & $\mathrm{Mn}, \mathrm{Fe}, \mathrm{Pb}$ & 4,1 & $\mathrm{Ni}, \mathrm{Fe}$ \\
\hline Immune system & 8,5 & $\mathrm{As}$ & 4,3 & $\mathrm{As}$ & 5,4 & $\mathrm{As}$ \\
\hline Bones & 11.8 & $\mathrm{Sr}$ & - & - & - & - \\
\hline
\end{tabular}


High risks of functional damage $\left(\mathrm{HI}>5.0^{4}\right)$ are predicted as regards digestive organs, the central nervous system, and the immune system for people living in all the examined geochemical provinces. There were moderate risks $(3.0<\mathrm{HI} \leq 5.0)$ of damage to the immune system and kidneys (for Koyvinskaya and Chusovskaya provinces), and blood (for Sylvenskaya and Chusovskaya provinces) [19].

High risks of damage to bones are characteristic for Sylvenskaya province due to high natural Sr concentrations in drinking water.

We didn't set a task to compare risk levels with actual population morbidity in this work. But still, research performed by some experts is well in line with our results. Thus, O. Yu. Ustinova et al. performed profound clinical and laboratory research and confirmed adverse effects produced by $\mathrm{Mn}$ contained in drinking water on children's health; these effects became obvious through neuro-vegetative dysfunctions [20]. There are data on increased $\mathrm{Sr}$ concentration registered in blood of people who consumed water with high $\mathrm{Sr}$ concentration. Biological aged of exposed people didn't correspond to proper one and musculoskeletal system pathology (posture disorders, deformation of the spinal column and feet) were registered among such people 2.5-10 times more frequently than in the reference group [21].

Conclusion. Our research revealed that geochemical provinces are characterized with different concentrations of such hazardous metals as $\mathrm{Cr}, \mathrm{Ni}$, $\mathrm{Pb} . \mathrm{Mn}, \mathrm{Fe}$, and others, in rocks and soils; it can exert substantial influence on quality of drinking water supplied to population who live within these geochemical provinces.

Absence or rare violations of hygienic standards don't guarantee complete safety of drinking water when its structure is formed under complicated hydrogeochemical conditions.

When some carcinogenic admixtures $(\mathrm{Cd}, \mathrm{Cr}$, $\mathrm{Ni}, \mathrm{As}$, and $\mathrm{Pb}$ ) jointly occur in natural and drinking water, it can cause unacceptable population health risks. Carcinogenic risk in the examined provinces of Perm region amounts to $4 * 10-3$ (in the worst exposure scenario) which is ranked as De manifestis Risk. Such risk level requires immediate actions aimed at its reduction from decision makers. Unacceptable non-carcinogenic risks are caused by joint occurrence of As, Mn, Sr, and some other compounds in drinking water. The highest risks occurred on the examined territories in relation to gastrointestinal tract diseases ( $\mathrm{HI}$ is up to 10.9; basic risk factors are $\mathrm{Cr}$ and its compounds); musculoskeletal system diseases (HI is up to 11.8; basic factor is $\mathrm{Sr}$ in water ), and central nervous system diseases (HI is up to 11.8 , basic factors are as, $\mathrm{Mn}$, and $\mathrm{Pb}$; contributions made by the elements into the overall risk were different in different provinces). Obviously, it is necessary to work out and implement a system of activities aimed at reducing health risks and at informing all the concerned parties about these risks, including water supplying organizations, population, and local authorities.

We didn't reveal any authentic relationships between average concentrations of elements in the earth crust in a geochemical province and concentrations of admixtures in drinking water in our research. But still, the highest $\mathrm{Cd}$ and $\mathrm{Pb}$ concentrations were detected exactly in drinking water in those provinces where their concentrations in rocks and soils were the highest. In some cases, when a hazardous element is contained in the earth crust in high concentrations, its content is not measured in drinking water. In relation to that we recommend water supplying organizations and sanitary surveillance bodies to take into account specific features of a geochemical province and include admixtures that occur in high concentrations in the environment into monitoring and laboratory research programs.

As reference concentrations of metals are very low, it seems advisable to improve procedures for quantitative determination of elements in drinking water.

Funding. Our research was not granted any sponsors' support.

A conflict of interests. The authors state there is no conflict of interests. 


\section{References}

1. Ivleva I.A., Alekseev L.S., Boldin A.V. Bar'ernye funktsii tekhnologii podgotovki podzemnykh vod dlya khozyaistvenno-pit'evykh tselei [Barrier Functions of Ground Water Treatment Technologies for Domestic Purposes]. Vodosnabzhenie i sanitarnaya tekhnika, 2007, no. 9-2, pp. 33-40 (in Russian).

2. Chudnovskii S.M., Likhacheva O.I., Odintsov V.V. Optimizatsiya protsessov upravleniya traditsionnymi tekhnologiyami podgotovki pit'evoi vody [Conventional technologies of drinking water treatment: managerial processes optimization]. Evraziiskii soyuz uchenykh, 2015, vol. 14, no. 5-3, pp. 14-16 (in Russian).

3. Chernikov V.A., Yunusov Kh.B. Otsenka ekologicheskogo sostoyaniya presnykh vod i sovremennye effektivnye metody ee ochistki ot zagryaznenii [Assessment of ecological situation with fresh water and up-to-date efficient techniques for its purification from admixtures]. AgroEkoInfo, 2017, vol. 27, no. 1, pp. 7 (in Russian).

4. Nordstrom D.K. Worldwide occurrences of arsenic in ground water. Public health. Science, 2002, vol. 296, no. 5576, pp. 2143-2145.

5. Khorasanipour M., Esmaeilzadeh E. Geo-genic arsenic contamination in the Kerman Cenozoic Magmatic Arc, Kerman, Iran: Implications for the source identification and regional analysis. Applied Geochemistry, 2015, vol. 63, pp. 610-622.

6. Mukherjee A., Bhattacharya P., Savage K., Foster A., Bundschuh J. Distribution of geogenic arsenic in hydrologic systems: controls and challenges. Journal of Contaminant Hydrology, 2008, vol. 99, no. $1-4$, pp. $1-7$.

7. Duz M.Z., Sagirdag M., Çelik K.S., Hasan M.A., Kilinç E. Geochemical multi-element ICP-OES analysis of borehole waters from SE Anatolia. Atomic Spectroscopy, 2016, vol. 37, no. 2, pp. 43-49.

8. S Ariunbileg., Gaskova O., Vladimirov A., Battushig A., Moroz E. Spatial distribution of uranium and metalloids in groundwater near sandstone-type uranium deposits, Southern Mongolia. Geochemical Journal, 2016, vol. 50, no. 5, pp. 393-401.

9. Chandio T.A., Khan M.N., Sarwar A. Fluoride estimation and its correlation with other physicochemical parameters in drinking water of some areas of Balochistan, Pakistan. Environmental Monitoring and Assessment, 2015, vol. 187, no. 8, pp. 531.

10. Zakutin V.P., Golitsin M.S., Shvets V.M. Aktual'ny problemy izucheniya i otsenki kachestva podzemnykh pit'evykh vod [Current issues in the study and quality assessment of drinking groundwater]. Vodnye resursy, 2012, vol. 39, no. 5, pp. 485-495 (in Russian).

11. Krainov S.R., Ryzhenko B.N., Shvets V.M. Geokhimiya podzemnykh vod. Teoreticheskie, prakticheskie i ekologicheskie aspekty [Geochemistry of underground waters. Theoretical, practical, and ecological aspects]. Moscow, TsentrLitNefteGekh Publ., 2012, 672 p. (in Russian).

12. Abdulmutalimova T.O., Kurbanova L.M., Guseinova A.Sh., Ramazanov O.M., Mammaev B.O. Otsenka vliyaniya prirodnykh gidrogeokhimicheskikh provintsii na kachestvo pit'evykh vod i zdorov'e naseleniya (na primere Respubliki Dagestan) [Assessment of influence exerted by hydrogeochemical provinces on drinking water quality and population health (on the example of Dagestan)]. Trudy Instituta geologii Dagestanskogo nauchnogo tsentra RAN, 2016, no. 66, pp. 231-235 (in Russian).

13. Voteiko L.G. Selenovyi status i narusheniya funktsii pochek v usloviyakh Zabaikal'skoi biogeokhimicheskoi provintsii [Selenium status and kidney function disorders in conditions of Zabaikalje biogeochemical provinces]. Ekologiya cheloveka, 2007, no. 1, pp. 12-15 (in Russian).

14. Abramkin A.V. K voprosu o biogeokhimicheskikh provintsiyakh i gigienicheskoi otsenke kachestva pit'evoi vody [The question of biogeochemical provinces and hygienic drinking water quality assessment]. Sciences of Europe, 2016, vol. 8, no. 8-1, pp. 18-22 (in Russian).

15. Chaslavsky M., Danikhelka P., Krzhizh L., Pashkovskii I.S., Sukhankova Ya. Radon v podzemnykh vodakh kak istochnik riska dlya zdorov'ya naseleniya [Radon in ground water as a factor of risk for human health]. Geoekologiya, inzhenernaya geologiya, gidrogeologiya, geokriologiya, 2010, no. 3, pp. 270-275 (in Russian).

16. Atlas Permskogo kraya [Perm region atlas]. In: A.M. Tartakovskii, ed. Perm', Perm. gos. nats. issled. un-t Publ., 2012, 124 p. (in Russian).

17. Shiryaeva I.A., Popova E.V. Tyazhelye metally v pit'evykh vodakh razlichnykh prirodnykh geokhimicheskikh provintsii Permskogo kraya kak faktory kantserogennogo riska dlya zdorov'ya naseleniya [Heavy metals in drinking water on geochemical provinces in the Perm region as factors of carcinogenic risk to protect public health]. Vestnik Permskogo universiteta. Seriya: Biologiya, 2014, no. 4, pp. 89-96 (in Russian). 
18. Zaitseva N.V., Popova A.Yu., Onishchenko G.G., May I.V. Aktual'nye problemy pravovoi i nauchnometodicheskoi podderzhki obespecheniya sanitarno-epidemiologicheskogo blagopoluchiya naseleniya Rossiiskoi Federatsii kak strategicheskoi gosudarstvennoi zadachi [Current problems of regulatory and scientificmedical support for the assurance of the sanitary and epidemiological welfare of population in the Russian Federation as the strategic government task]. Gigiena $i$ sanitariya, 2016, vol. 95, no. 1, pp. 5-9 (in Russian).

19. Shvets V.M., Krainov S.R. Regional'nye gidrogeokhimicheskie provintsii normiruemykh komponentov presnykh pit'evykh podzemnykh vod [Regional hydrogeochemical provinces of the normalized components of the fresh drinking groundwater]. Izvestiya vysshikh uchebnykh zavedenii. Geologiya $i$ razvedka, 2014, no. 5, pp. 33-37 (in Russian).

20. O Maklakova.A., Ustinova O.Yu., Luzhetskii K.P., Baidina A.S., Mazunina D.L., Permyakov I.A., Osheva L.V. Neirovegetativnye disfunktsii u detei, prozhivayushchikh na territorii s povyshennym urovnem margantsa v pit'evoi vode [Neurovegetative dysfunctions at children, living in the territory with the raised level of manganese in drinking water]. Izvestiya Samarskogo nauchnogo tsentra Rossiiskoi akademii nauk, 2013, vol. 15, no. 3-6, pp. 1845-1849 (in Russian).

21. Vandysheva A.Yu., Luzhetsky K.P., Ustinova O.Yu., Shcherbakov A.A. Tempy biologicheskogo sozrevaniya i osobennosti narushenii kostno-myshechnoi sistemy u detei v usloviyakh peroral'noi ekspozitsii strontsiya s pit'evoi vodoi [Rates of the biological maturation and particularities of violation of the locomotor system in children under conditions of oral exposure to strontium in drinking water]. Zdorov'e naseleniya i sreda obitaniya, 2015, vol. 273, no. 12, pp. 45-47 (in Russian).

Fomenko A.N., Aristov V.A., Maklakova O.A., Khoroshavin V.A. Factors and population health risks under exposure to components detected in drinking water within natural hydrogeochemical provinces in Perm region. Health Risk Analysis, 2018, no. 3, pp. 54-62. DOI: 10.21668/health.risk/2018.3.06.eng

Received: 16.08 .2018

Accepted: 21.09 .2018

Published: 30.09 .2018 